\title{
PENGARUH PENYULUHAN TERHADAP PENGETAHUAN IBU HAMIL TRIMESTER III TENTANG NOCTURIA DI BPS Ny. EMY DESA MANGUNREJO KECAMATAN NGADILUWIH KABUPATEN KEDIRI TAHUN 2015 \\ (The Effectiveness of Counseling to the Knowledge of Pregnant Women about Nocturia in Trimester III in BPS Ny Emy Mangunrejo Village Ngadiluwih District Kediri 2015)
}

\author{
Resmita Ardiansyah \\ Akademi Kebidanan Medika Wiyata \\ email: machsun_s@yahoo.com
}

\begin{abstract}
Pregnancy involves emotional and physical changes of the mother as well as the social changes in the family. At 28 weeks gestation, fetal head began to descend into the pelvis so that pressing the bladder and cause Frequent urination. The purpose of this study was to determine the effectiveness of counseling to the extension of the third trimester pregnant women knowledge about nocturia. The design of the study used a pre-experimental design approach One Group Pre-Post Test Design. The population was the entire third trimester pregnant women with the sample of 22 respondents taken by total sampling technique. The data collected by questionnaire and tested with paired sample t test. Respondents with a good knowledge criteria was 21 respondents (95.5\%), respondents with sufficient knowledge criteria was 1 respondent (4.5\%). Comparisons in this research was $t<t_{\text {table }}(-9.1135<-$ 2.080 ) with $23.0 \%$ of samples obtained difference with $38.4 \%$. Counseling was important to increase knowledge of third trimester pregnant women about nocturia.
\end{abstract}

Keywords: education, knowledge, pregnant women, nocturia

\begin{abstract}
Abstrak: Kehamilan melibatkan perubahan fisik maupun emosional dari ibu serta perubahan sosial di dalam keluarga. Pada usia kehamilan 28 minggu, Kepala janin mulai turun ke dalam panggul sehingga menekan kandung kemih dan mengakibatkan Sering BAK. Tujuan penelitian ini adalah untuk mengetahui pengaruh penyuluhan terhadap pengetahuan ibu hamil trimester III tentang nocturia. Pada penelitian ini desain yang digunakan adalah desain pra-eksperimental dengan pendekatan One Group Pra-Post Test Design. Populasi seluruh ibu hamil trimester III dengan sampel 22 responden diambil dengan teknik total sampling. Cara pengumpulan data mengguanakan kuesioner dan diuji mengguanakan uji t sampel berpasangan. Responden dengan kriteria pengetahuan baik sejumlah 21 responden $(95,5 \%)$, responden dengan kriteria pengetahuan cukup sejumlah 1 responden (4,5\%). Perbandingan pada penelitian ini yaitu $\mathrm{t}_{\text {hitung }}<\mathrm{t}_{\text {tabel }}(-9,1135<-2,080)$ dengan diperoleh perbedaan 23,0\% sampel dengan 38,4\%. Pemberian konseling, dan penyuluhan untuk meningkatkan pengetahuan ibu hamil trimester III tentang nocturia.
\end{abstract}

Kata Kunci: penyuluhan, pengetahuan, ibu hamil, nocturia

Masa kehamilan dibagi dalam 3 triwulan yaitu triwulan pertama dimulai dari konsepsi sampai 3 bulan, triwulan kedua dari bulan keempat sampai 6 bulan, triwulan ketiga dari bulan ketujuh sampai 9 bulan. Lamanya hamil normal adalah 280 hari (40 minggu atau 9 bulan 7 hari) dihitung dari hari pertama haid terakhir. Kehamilan melibatkan perubahan fisik maupun emosional dari ibu serta perubahan sosial di dalam keluarga (Prawiroharjo, 2008:89). 
Nocturia adalah urinasi berlebihan pada malam hari. Vesica urinaria sangat berdekatan dengan rectum maupun organ-organ tractus genitalis dan semua organ yang diinervasi oleh saraf dari plexus sacralis. Begitu juga pada kehamilan, karena perkembangan fetus, semuanya ini akan memakan tempat sehingga mempersempit ruang pada pelvis. Bila satu organ membesar, maka organ yang lain akan mengalami tekanan, dan pada kehamilan tidak jarang terjadi gangguan berkemih pada saat kehamilan dan persalinan maupun selama periode postnatal (Verralls, 2003:89).

Kehamilan membutuhkan perhatian yang cukup serius. Umumnya, berbagai keluhan dapat terjadi selama kehamilan. Beberapa wanita merasa kewalahan dalam menghadapi keluhan tersebut. Apalagi, jika kehamilan ini merupakan yang pertama kalinya. Berikut ini, beberapa keluhan yang sering terjadi selama proses kehamilan, mual dan muntah, ngidam, pingsan, payudara besar dan tegang, sering buang air kecil, sulit buang air besar, sakit pinggang, varises, keputihan (Huliana, 2008:32-35).

Pada akhir kehamilan kepala janin mulai turun ke pintu atas panggul keluhan sering kencing akan timbul lagi karena kandung kencing akan mulai tertekan kembali. Selain itu juga terjadi hemodilusi menyebabkan metabolisme air menjadi lancar. Pada kehamilan tahap lanjut, pelvis ginjal kanan dan ureter lebih berdilatasi daripada pelvis kiri akibat pergeseran uterus yang berat ke kanan akibat terdapat kolon rektosigmoid di sebelah kiri (Kusmiyati, 2008: 65).

Rahim yang tumbuh membesar akan menekan kandung kemih. Untuk menghindari bangun di malam hari, batasilah minum menjelang tidur. Saat batuk, tertawa, atau bersin kadang-kadang keluar air kencing sedikit. Untuk menghindari hal ini, lakukan latihan panggul dengan teratur, hindari sembelit dan sering-seringlah mengosongkan kandung kemih (Prasetyo, 2008:98)

Nocturia ini dapat diatasi, upaya dalam mengatasi nocturia adalah sebagai berikut banyak minum pada siang hari. Jangan mengurangi porsi air minum di malam hari, kecuali apabila nocturia menganggu tidur sehingga menyebabkan keletihan. Membatasi minuman yang mengandung bahan cafein (teh, kopi, cola). Bila tidur (khususnya malam hari) posisi miring dengan kedua kaki ditinggikan untuk meningkatkan diuresis (Marmi, 2011:134).

Hasil studi pendahuluan pada bulan September 2015 yang dilaksanakan oleh peneliti di BPS Ny.
Emy menunjukkan bahwa banyak ditemui ibu hamil yang tidak mengetahui tentang nocturia terutama ibu hamil trimester III, dari 24 ibu hamil trimester III 20 ibu hamil trimester III tidak mengetahui sedangkan 4 ibu hamil trimester III mengetahui tentang nocturia.

Berdasarkan urain di atas maka peneliti tertarik untuk melakukan penelitian mengenai "Pengaruh Penyuluhan Terhadap Pengetahuan Ibu Hamil Trimester III Tentang Nocturia Di BPS Ny. Emy Desa Mangunrejo Kec. Ngadiluwih Kabupaten Kediri.

\section{BAHAN DAN METODE}

Desain penelitian ini menggunakan rancangan penelitian pra-eksperimental dengan pendekatan One Group Pra-Post Test Desaign dengan rancangan pra test dan post test group desain.

Populasi dalam penelitian ini adalah seluruh ibu hamil trimester III di BPS Ny. Emy Desa Mangunrejo Kec. Ngadiluwih Kab. Kediri. Sampel dalam penelitian ini adalah semua ibu hamil trimester III yang ikut dalam penyuluhan di BPS Ny. Emy Desa Mangunrejo Kec. Ngadiluwih Kab. Kediri yang berjumlah 22 responden.

Penelitian ini menggunakan teknik Total Sampling yaitu Pengambilan sampel dengan mengambil seluruh kasus atau responden (Sugiyono, 2009:85). variable independent penelitian ini adalah penyuluhan tentang nocturia.

Dalam penelitian ini pengetahuan hamil tentang nocturia sebelum dan sesudah Penyuluhan. Lokasi Penelitian Tempat penelitian di BPS Ny. Emy Desa Mangunrejo Kec. Ngadiluwih Kab. Kediri. Waktu Penelitian Penelitian dilaksanakan pada bulan Desember 2015. Analisa data pada penelitian ini adalah sebagai berikut: Editing (Penyuntingan data). Membuat Lembaran Kode (Coding Sheet). Scoring. Memasukan data (Data Entry). Tabulasi. Analisa bivariat (Hubungan Variabel independent dan Dependen)

\section{HASIL PENELITIAN \\ Pengetahuan ibu hamil sebelum penyuluhan nocturia}

Tabel 1. Pengetahuan ibu hamil trimester III sebelum penyuluhan nocturia

\begin{tabular}{clcc}
\hline No & Kategori & f & \% \\
\hline 1 & Baik & 5 & 22,7 \\
2 & Cukup & 4 & 18,2 \\
3 & Kurang & 13 & 59,1 \\
\hline & Jumlah & 22 & 100 \\
\hline
\end{tabular}


Berdasarkan tabel 1 di atas dari 22 responden sebelum diberi penyuluhan mayoritas memiliki pengetahuan kurang sebanyak 13 responden $(59.1 \%)$, yang memiliki pengetahuan baik 5 responden (22.7\%) dan berpengetahuan cukup 4 responden $(18,2 \%)$.

\section{Pengetahuan ibu hamil trimester III sesudah penyuluhan nocturia}

Tabel 2. Pengetahuan ibu hamil trimester III sesudah penyuluhan nocturia

\begin{tabular}{clcc}
\hline No & Kategori & f & \% \\
\hline 1. & Baik & 21 & 95.5 \\
2. & Cukup & 1 & 4.5 \\
3. & Kurang & 0 & 0 \\
\hline & Jumlah & 22 & 100 \\
\hline
\end{tabular}

Berdasarkan tabel 2 di atas dari 22 responden sesudah diberi penyuluhan mayoritas memiliki pengetahuan baik sebanyak 21 responden $(95.5 \%)$ dan yang memiliki pengetahuan cukup 1 responden $(4.5 \%)$.

\section{Pengetahuan Ibu Hamil Trimester III Tentang Nocturia Sebelum Dan Sesudah Penyuluhan}

Tabel 3. Tabulasi silang pengetahuan ibu hamil trimester III tentang nocturia sebelum dan sesudah penyuluhan

\begin{tabular}{clccc}
\hline Pengetahuan & \multicolumn{2}{l}{ Sebelum } & \multicolumn{2}{c}{ Sesudah } \\
\cline { 2 - 5 } & $\Sigma$ & $\%$ & $\Sigma$ & $\%$ \\
\hline Baik & 5 & 22,7 & 21 & 95,5 \\
Cukup & 4 & 18,2 & 1 & 4,5 \\
Kurang & 13 & 59,1 & 0 & 0 \\
\hline Total & 22 & 100 & 22 & 100 \\
\hline
\end{tabular}

Berdasarkan tabel 3 di atas dari 22 responden sebelum diberi penyuluhan mayoritas memiliki pengetahuan kurang sebanyak 13 responden $(59,1 \%)$ pengetahuan baik 5 responden $(22,7 \%)$, pengetahuan cukup 4 responden $(18,2 \%)$ yang memiliki pengetahuan cukup 1 responden (4.5\%). Setelah diberi penyuluhan pengetahuan responden mayoritas memiliki pengetahuan baik sebanyak 21 responden (95,5\%), berpengetahuan cukup 1 responden $(4,5 \%)$, dan tidak ada responden yang berpengetahuan kurang (0\%). Hal tersebut membuktikan bahwa sesudah diberi penyuluhan pengetahuan responden meningkat.

\section{PEMBAHASAN}

Hasil penelitian ini menunjukkan bahwa pengetahuan ibu kurang sebagian besar didominasi oleh ibu yang pendidikan terakhirnya SMP yaitu sebanyak 7 responden $(31,8 \%)$ dari total 13 responden yang pengetahuannya kurang.

Pengetahuan ibu kurang tentang nocturia pada penelitian ini sebagian besar didominasi ibu dengan pendidikan terakhir SMP karena mayoritas ibu yang mengikuti penyuluhan nocturia berpendidikan terakhir SMP. Ibu hamil trimester III, setelah SMP tidak melanjutkan pendidikan ke jenjang selanjutnya karena tidak terdapatnya biaya, sudah banyak yang menikah, pendapat dari ibu adalah seorang perempuan tidak perlu untuk melanjutkan pendidikan yang lebih tinggi karena nantinya tetap akan hanya menjadi ibu rumah tangga. Meskipun ibu sudah menyelesaikan pendidikan terakhir SMP ternyata selama ini pengetahuan tentang nocturia hanya diperoleh dari tenaga kesehatan dan tetangga.

Pengetahuan ibu kurang tentang nocturia sebagian besar didominasi oleh ibu yang bekerja sebagai ibu rumah tangga sebanyak 9 responden $(40,9 \%)$ dari total 13 responden yang pengetahuannya kurang.

Berdasarkan hasil penelitian ini didapatkan bahwa pengetahuannya ibu baik sebagaian besar didominasi oleh ibu rumah tangga karena disebabkan berbagai faktor.

Pekerjaan sebagai ibu rumah tangga merupakan yang dapat menyita waktu sehingga ibu untuk mendapat informasi tentang nocturia hanya memperoleh informasi dari tenaga kesehatan dan tetangga.

Berdasarkan hasil penelitian sumber informasi yang di dapat diperoleh dari petugas kesehatan yaitu sebanyak 5 responden $(22,7 \%)$. Mayoritas responden yang mendapat Informasi dari tenaga kesehatan pengetahuanya baik 3 reponden $(50,0 \%)$ karena informasinya mudah dipahami karena pasien biasanya diberi contoh.

\section{Pengetahuan ibu hamil trimester III Tentang Pencegahan Nocturia Sesudah Penyuluhan}

Berdasarkan hasil penelitian tentang pengaruh penyuluhan terhadap pengetahuan ibu hamil trimester III tentang nocturia dapat diketahui bahwa pengetahuan ibu hamil sesudah penyuluhan mayoritas baik yaitu 21 responden $(95,5 \%)$. 
Pendapat dari ibu hamil trimester III di BPS Ny. Emy bahwa pencegahan nocturia merupakan hal yang masih belum dimengerti oleh ibu. Selama ini mereka hanya berpedoman pada adat, keturunan, kebiasaan dan pengalaman. Di samping itu, keterbatasan fasilitas, sikap dan perilaku para petugas kesehatan terhadap perilaku kesehatan juga akan mendukung dan memperluas terbentuknya perilaku (Notoadmodjo, 2007:123).

Pendapat penelitian keterkaitan dengan nocturia bahwa masih banyak ibu yang pengetahuannya baik setelah diberi penyuluhan. Oleh karena itu, diharapkan bagi petugas kesehatan khususnya bidan, mampu memberikan KIE tentang nocturia yang benar dan mudah dimengerti oleh ibu.

\section{Pengaruh Penyuluhan Terhadap Pengetahuan Ibu Hamil Tentang Nocturia}

Hasil penelitian dengan menggunakan rumus uji t sampel berpasangan dalam penghitungan manual didapatkan hasil angka koefisien yaitu -9.1135 dengan $\alpha=0,05$ dan $n=22$, maka $t_{\text {tabel }}=-2,831$, perbandingan pada penelitian ini yaitu $\mathrm{t}_{\text {hitung }}<\mathrm{t}_{\text {tabel }}$ $(-9.1135<-2,08)$. Maka Ho ditolak, artinya ada pengaruh antara pengetahuan ibu tentang nocturia sebelum dan sesudah penyuluhan. Pengaruh pengetahuan antara $23,0 \%$ sampai dengan $38,4 \%$ artinya semakin sering memperoleh penyuluhan nocturia maka semakin baik tingkat pengetahuan ibu tentang nocturia.

Didapatkannya ada pengaruh penyuluhan terhadap pengetahuan ibu hamil trimester III tentang nocturia oleh berbagai faktor responden yang memahami tentang pengertian nocturia, penyebab nocturia, penanganan nocturia, dampak nocturia.

Dalam hal ini penyuluhan mempengaruhi pengetahuan ibu hamil dari yang sebelum penyuluhan mempunyai pengetahuan kurang dan sesudah adanya penyuluhan mempunyai pengetahuan baik tentang nocturia.

Dalam pemberian penyuluhan nocturia kepada responden penyuluh menggunakan bahasa yang mudah dimengerti sehingga responden dengan mudah dalam memahami materi penyuluhan yang diberikan oleh penyuluh. Keberhasilan penyuluhan juga dipengaruhi oleh metode dalam penyuluhan yaitu materi dan waktu. Metode yang digunakan penyuluh adalah ceramah dan tanya jawab. Sehingga responden bisa langsung bertanya mengenai hal yang mereka belum mengerti sedangkan media yang digunakan adalah Leaflet.

\section{DAFTAR RUJUKAN}

Kusmiyati, Y. 2009. Perawatan Ibu Hamil. Yogyakarta: Fitramaya.

Marmi. 2011. Asuhan Kebidanan Pada Masa Antenatal. Yogyakarta: Pustaka Pelajar.

Notoatmodjo, S. 2010. Metodologi Penelitian Kesehatan. Jakarta: PT Rineka Cipta.

Prasetyono, D. 2008. Bimbingan Persiapan dan Perawatan Kehamilan. Yogyakarta: DIVA press.

Prawirohardjo, S. 2008. Ilmu Kebidanan. Jakarta: Yayasan Bina Pustaka Sarwono Prawirohardjo.

Sugiyono. 2010. Metodologi Penelitian Kuantitatif dan Kualitatif $R \& D$. Bandung: Alfabeta.

Fisiologi Terapan Dalam Kebidanan. Jakarta: EGC. 